\title{
Effect of Combined Stabilization by Lime and Cement on Hydraulic Properties of Clayey Soil Selected From Mosul Area
}

\author{
Dr. Suhail Idrees Khattab \\ Professor \\ Mohammed Mukhlif Aljobouri \\ Assistant Lecturer \\ Civil Engineering Department / College of Engineering / University of Mosul
}

\begin{abstract}
This paper is aimed to study some of the hydraulic properties (permeability and water retention) of a stabilized clayey soil selected from Mosul area. The optimum lime stabilization percentage was found to be $4 \%$. Cement amounts of $6 \%$ and $18 \%$ are needed to achieve a minimum unconfined compressive strength of 1400 and $5600 \mathrm{kPa}$ respectively "suggested limits for stabilized soil suitable as a base course". For the same indicated range of strength, a combination of lime-cement ratios of 1-3\% and 2-9\% respectively were found to be sufficient to achieve this limit. Permeability of natural soil was found to increase with treatment of lime, cement and lime-cement. A maximum increasing in permeability about 17 fold was found using $4 \%$ lime. While the permeability was 1.2 folds as a minimum increase when treating the soil with $18 \%$ cement. The soil-water characteristics curve shows that (S-Shape) curves were maintained for natural and stabilized soil.

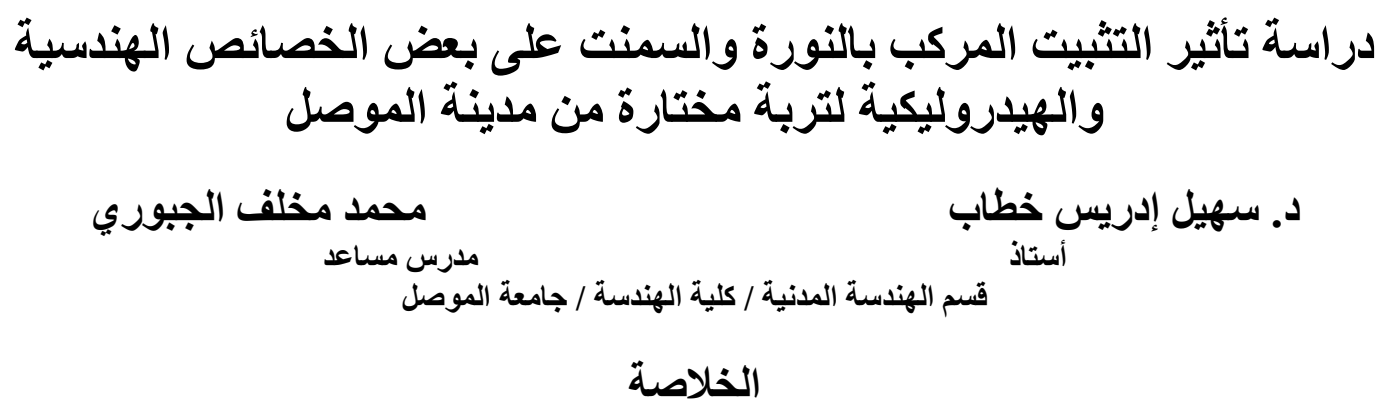

يهدف البحث إلى دراسة تأثير بعض الخصائص الهيلروليكية (النفاذية والإحتفاظ بالماء) لتربـة طينية مثبتة مختارة من

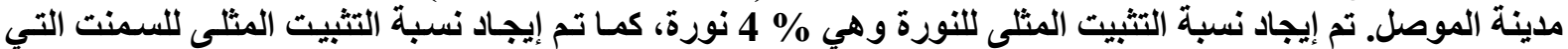

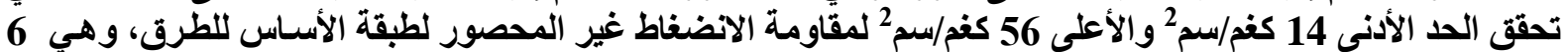

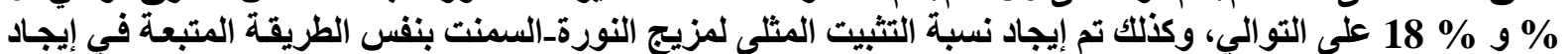
النسبة المثلى للسمنت، وقُّ وجد أن النسبتين

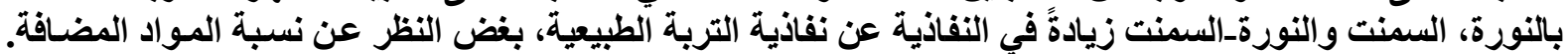

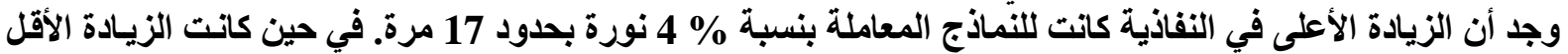

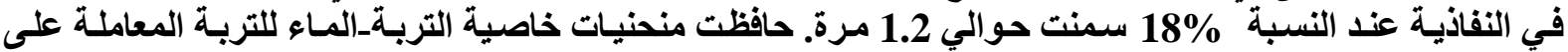

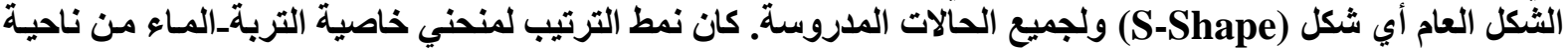
قابلية الاحتفاظ بالماء يزداد مع زيادة نسبة المضافات.
\end{abstract}




\section{Introduction}

The soil at any particular locality could be unsuited, wholly or partially, to the requirements of the construction engineer. A basic decision must therefore be made, whether to [6]:

1. Accept the site material as it is, and design to standards sufficient to meet the restrictions imposed by its existing quality.

2. Remove the site material, and replace with a superior material.

3. Alter the properties of the existing soil so as to create a new site material capable of better meeting the requirements of the task in hand, and this is known as soil stabilization.

Soil stabilization is the mechanical, physical, or chemical treatment of a soil designed to increase or maintain stability of the soil or otherwise to improve the engineering properties of the soil, enabling the material to serve as a better construction material [4].

Therefore there are different ways to stabilize soil [4]:

1. Mechanical Stabilization (compaction).

2. Chemical stabilization involves addition of chemicals to the soil, particularly lime, cement, asphalt. Sometimes using two types of stabilizers or more and this known as combined stabilization.

3. Physical stabilization refers to addition of particulate material to the soil, for example clay and sand.

The most methods of soil stabilization are: lime, cement, and asphalt. In this paper combined stabilization by lime and cement of soil selected from Mosul area in Iraq was studied.

Lime will primarily react with medium, moderately fine, and fine-grained soils to produce decreased elasticity, increased workability, reduced swell, and increased strength $[1,12]$. The strength of lime-treated soil develops with increasing addition of lime until an optimum lime content is reached beyond which the strength continues to increase at a reduced rate or begins to decline. [3].

A wide range of soil types may be stabilized using Portland cement. It is generally more effective and economical to use with granular soils due to the ease of pulverization and mixing and the smaller quantities of cement required [9]. Fine-grained soils of low to medium plasticity can also be stabilized with cement, but not as effectively as coarse-grained soils. The strength of soil treated with cement increasing with increase in cement content, where a linear relationship can be used to approximate the relationship between strength and cement content [7].

Sometimes combined stabilization is used for the following reasons [7]:

1. Improving of the engineering properties of a certain soil to achieve best using.

2. Economic or environmental reasons.

3. One of the stabilizers in the combination compensates for the lack of effectiveness of the other in treating a particular aspect or characteristic of a given soil.

While cement cannot be used alone for highly plastic soils, lime can be used first to initiate action exchange and flocculation-agglomeration reaction and to produce immediate changes by reducing the plasticity and improving the workability of these soils. Addition of cement then ensures rapid strength development of the mixture. This is especially advantageous when rapid strength gain is required under cooler weather conditions [7].

Soil-water characteristics curve one of the important hydraulic properties; it is the relation between water content and soil suction. It is central to the engineering behavior of an unsaturated soil, and can be used as a means of deriving and linking soil behaviors such as permeability, shear strength and volume change [8]. The Main aim of this paper is studying the effect of combined stabilization on some hydraulic and engineering properties; the permeability and the soil water characteristic curve are studied as important properties which describe the changes which happened in the structure of soil selected from Mosul area when 
treated with lime-cement. The most important studied variable in this paper are: admixtures percentages, effect of curing times which reached to 90 days, and water content of specimens.

\section{Materials and Methods}

\section{Natural Soil}

The clayey soil was selected from Al Hadbaa quarter (Mosul city). The basic soil properties are summarized in Table 1. This clayey soil was classified as $\mathrm{CH}$.

The device of permeability test was made locally; the dimensions of compaction mold are $9.7 \mathrm{~cm}$ in diameter and $3.85 \mathrm{~cm}$ in height. It contains two outlets at the bottom of device to supply water during the test, and single outlet at the top to permit the water to exit. This device was made such that to help obtaining higher available degree of saturation by

Table 1. Basic properties of soil

\begin{tabular}{lc} 
Property & Value \\
\hline Liquid limit $(\%)$ & 56 \\
Plastic limit (\%) & 28 \\
Plasticity index (\%) & 28 \\
Specific gravity & 2.73 \\
Maximum dry density $\left(\mathrm{kN} / \mathrm{m}^{3}\right)$ & 15.69 \\
Optimum moisture content \% & 23 \\
UCS & $\mathrm{CH}$
\end{tabular}
expulsion air bubbles from top.

Soil-water characteristics curves were established within suction range of $(0-1,000,000) \mathrm{kPa}$. Saturated solution method was used for the application of suction range (2700-325000) [10]. The other part of the curve was completed using the osmotic solution method, an osmotic membrane submerged in different solutions of Poly Ethylene Glycol (P.E.G) to give solutions of $(50,450) \mathrm{kPa}$. Small chunks $(5-10) \mathrm{g}$ of statically compacted soil samples were brought to saturation in distilled water. The soil chunks were then placed in desiccators of different chemical solutions, each one of them will cause certain suction. Equilibrium time was found to be 45 days for saturated solution method, and 21 days for the osmotic solution method.

Soil Treated with Cement

Portland cement was used in this paper; the method proposed by (Ingles \& Metcalf 1972) [6] was used in this paper to select the optimum cement content to stabilize soil. This method involve finding the unconfined compressive strength of cement stabilized soil samples treated with different percentages at a temperature of $25^{\circ} \mathrm{C}$ and 7 days curing time. It is clear from Table 2, that a limit of unconfined compressive strength of (14 to 56$) \mathrm{kg} / \mathrm{cm}^{2}$ and of cement treated soil is suitable to be utilized as a road base.

Table 2. Design criteria of cement treated soil [6]

\begin{tabular}{|l|c|c|c|c|c|}
\hline Purpose & \multicolumn{2}{|c|}{ U.C.S $^{[1]}$} & C.B.R & Swell & $\begin{array}{c}\text { Loss in } \\
\text { wet/dry test }^{[3]}\end{array}$ \\
\hline & $\mathrm{kgf} / \mathrm{cm}^{2}$ & $\left(\mathrm{Ibf} / \mathrm{In}^{2}\right)$ & & per cent & per cent $^{2}$ \\
\hline $\begin{array}{l}\text { Road sub-base, formation } \\
\text { backfill for trenches etc. } \\
\text { Road sub-base, base for } \\
\text { light traffic }\end{array}$ & $3.5-10.5$ & $(50-150)$ & $20-80$ & 2 & 7 \\
$\begin{array}{l}\text { Base for heavy traffic } \\
\text { Building blocks }\end{array}$ & $7-14$ & $(100-200)$ & $50-150$ & 2 & 10 \\
$\begin{array}{l}\text { Embankment protection } \\
\text { Floodways (too strong for } \\
\text { general use under thin } \\
\text { surfacing) }\end{array}$ & $14-56$ & $(200-800)$ & $200-600$ & 2 & 14 \\
\hline
\end{tabular}


[1] U.C.S cured seven days at constant moisture content. The loss of strength on soaking should not be more than 20 per cent.

[2] C.B.R. - Soaked four days.

[3] Durability test appropriate only where moisture penetration is likely to occur.

Higher cement contains may be required to meet this criterion.

[4] Lower strengths may be adequate for well-drained areas in the tropics.

Results showed that, $6 \%$ and $18 \%$ cement were the percentages that attain the lower and upper limit of unconfined compressive strength of road base respectively as shown in Figure (1). The results of unconfined compressive strength of soil samples treated with cement and soaked for 7 days show a maximum strength loss of $20 \%$.

The liquidity and plasticity limits of cement treated soil are shown in Table 3, the mellowing period was 10 minutes. It is clear that the addition of $6 \%$ and $18 \%$ cement turn the soil to non-plastic.

Table 3. Some engineering properties of cement treated soil.

\begin{tabular}{|c|c|c|c|c|}
\hline \multirow[b]{2}{*}{$\begin{array}{l}\text { Cement } \\
\text { percent }\end{array}$} & \multirow[b]{2}{*}{$\begin{array}{l}\mathrm{LL} \\
(\%)\end{array}$} & \multirow[b]{2}{*}{$\begin{array}{c}\text { PI } \\
(\%)\end{array}$} & \multicolumn{2}{|c|}{ Standard effort } \\
\hline & & & $\begin{array}{c}\mathrm{MDD} \\
\left(\mathrm{kN} / \mathrm{m}^{3}\right)\end{array}$ & $\begin{array}{c}\mathrm{OMC} \\
(\%)\end{array}$ \\
\hline 0 & 56 & 28 & 15.69 & 23 \\
\hline 6 & $\mathrm{NP}$ & NP & 15.5 & 24 \\
\hline 18 & $\mathrm{NP}$ & $\mathrm{NP}$ & 14.09 & 26 \\
\hline
\end{tabular}

\section{Soil Treated with Lime}

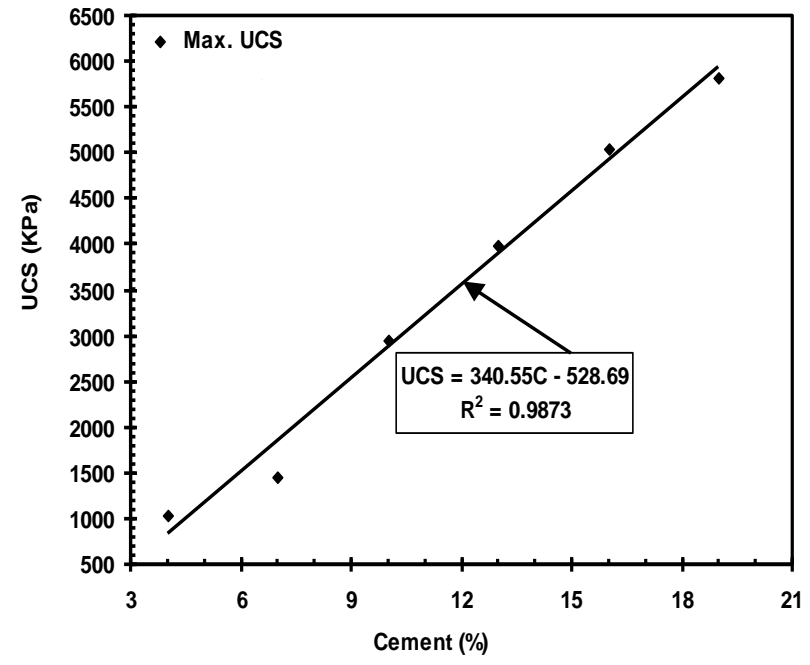

Figure 1. Relationship between maximum UCS and cement content of cement treated soil.

Hydrated lime $\mathrm{Ca}(\mathrm{OH})_{2}$ was used $\left(71.3 \% \mathrm{Ca}(\mathrm{OH})_{2} \& 6.1 \% \mathrm{CaO}\right)$. Stabilization percent (optimum lime percent) was found to be $4 \%$ lime based on dry weight using Edges \& Grim protocol [5] and Thompson mixture design [12]. To compare the soil samples treated with lime with that treated with cement, the same curing conditions of (temperature $25^{\circ} \mathrm{C}$ and curing time 7 days) were applied. Figure (2) shows that $4 \%$ lime should be used to obtain the uppermost of unconfined compressive strength $(1135 \mathrm{kPa})$. This value does not satisfy the lower limit of the unconfined compressive strength of soil used as a road base, Table 2. However, this percentage was choose in this paper to study the effect of lime on the permeability of stabilized soil and on the soil-water characteristics curve. The liquid and plastic limits of lime treated soil was shown in Table 4, the mellowing period was one hour. It is clear that a reduction of liquid limit values and decreasing the plasticity index with addition of lime percentage, and the soil turn to non-plastic at $3 \%$ lime.

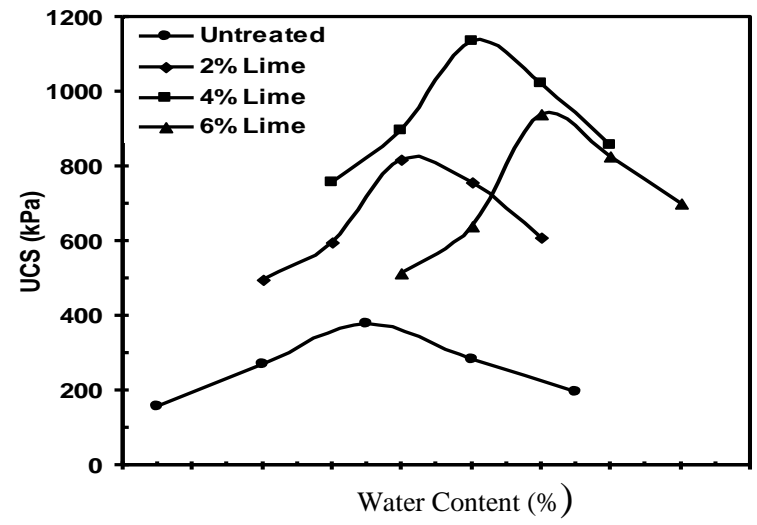

Figure 2. Relationship between UCS and water content of soil treated with different percentages of lime. 
Table 4. Some engineering properties of lime treated soil.

\begin{tabular}{|c|c|c|c|c|}
\hline \multirow{2}{*}{ Lime percent } & \multirow{2}{*}{$\begin{array}{l}\mathrm{LL} \\
(\%)\end{array}$} & \multirow{2}{*}{$\begin{array}{c}\text { PI } \\
(\%)\end{array}$} & \multicolumn{2}{|c|}{ Standard effort } \\
\hline & & & $\operatorname{MDD}\left(\mathrm{kN} / \mathrm{m}^{3}\right)$ & OMC (\%) \\
\hline 0 & 56 & 28 & 15.69 & 23 \\
\hline 1 & 52 & 13 & 15.27 & 24 \\
\hline 2 & 50 & 8 & 15.18 & 24 \\
\hline 3 & $\mathrm{NP}$ & $\mathrm{NP}$ & 15.02 & 25 \\
\hline 4 & NP & NP & 14.89 & 26 \\
\hline
\end{tabular}

\section{Soil Treated with Lime-Cement}

Lime-cement mixture of (1-3, 2-9) \% cured at a temperature of $25^{\circ} \mathrm{C}$ for 7 days were selected on the basis of achieving the lower and upper limit of unconfined compressive strength of soil treated with cement used as a road base, Table 2 [6]. Figure (3) shows the unconfined compressive strength of soil samples treated with lime-cement with different percentages prepared at optimum moisture content of natural soil. These percentages lie between the lower and upper limit of the percentages that used in lime-cement mixture ((1-3) \% lime and (3-10) \%

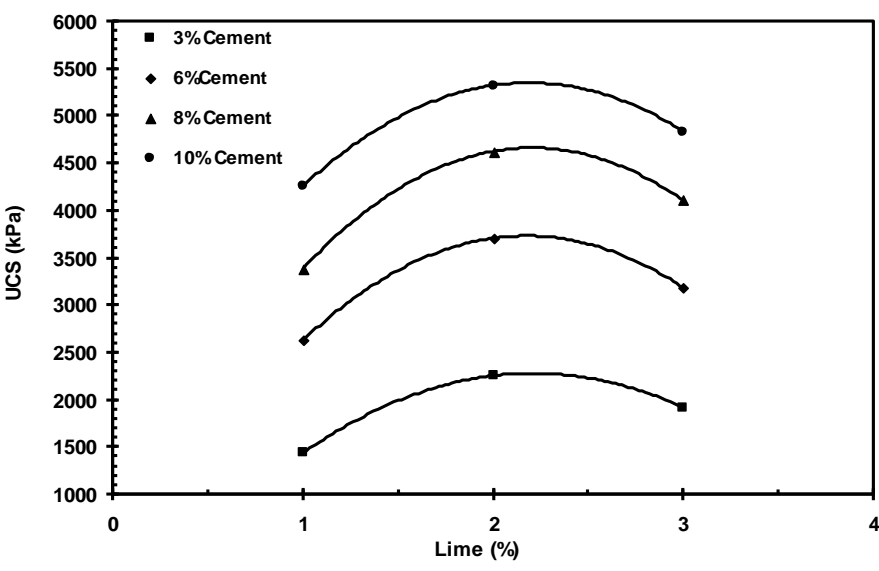

Figure 3. UCS of lime-cement treated soil samples at optimum moisture content.

cement) as an indicator to achieve the lower and upper limit of unconfined compressive strength of soil used as a road base. From this Figure, the lower and upper limits of unconfined compressive strength shown in (Table 2) could approximately be achieved using $1 \%$ and $2 \%$ lime respectively.

Figure (4) shows the unconfined compressive strength of soil samples treated using $(1 \%)$ lime with different percentages of cement prepared at different moisture contents. Then Figure (5) show that the sufficient amount of lime-cement to attain the above mentioned criteria was (1-3) \%.

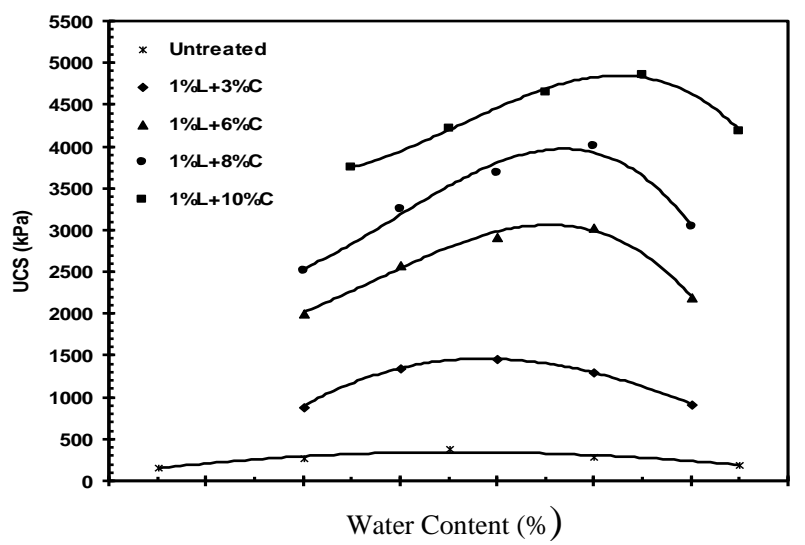

Figure (4). UCS of soil treated with $1 \%$ lime with different percentages of cement.

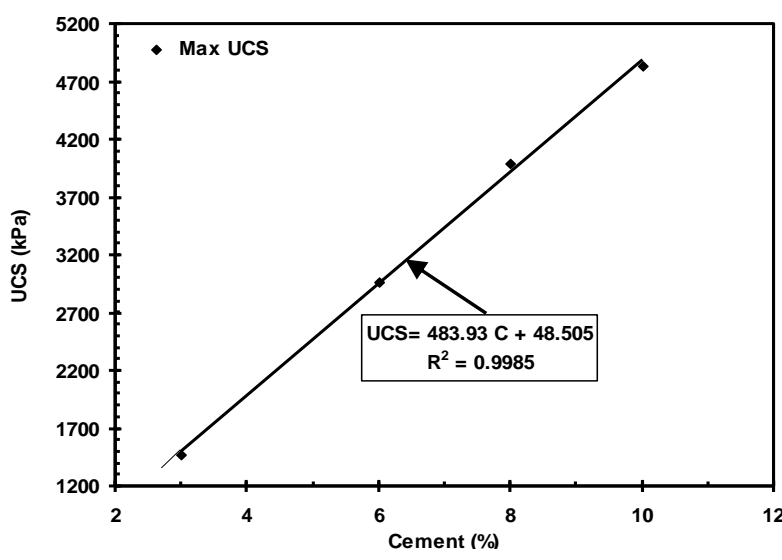

Figure 5. Relationship between maximum UCS and cement content of soil treated using $1 \%$ lime with different percentages of cement. 
On the other hand, Figures (6) and (7) show that (2-9) \% lime-cement are the required amount to obtain the upper limit of unconfined compressive strength stated in table 2 . It is worth mentioning here that, soaking of unconfined compressive strength of soil samples treated with lime-cement for 7 days show a strength loss not exceeding $20 \%$.

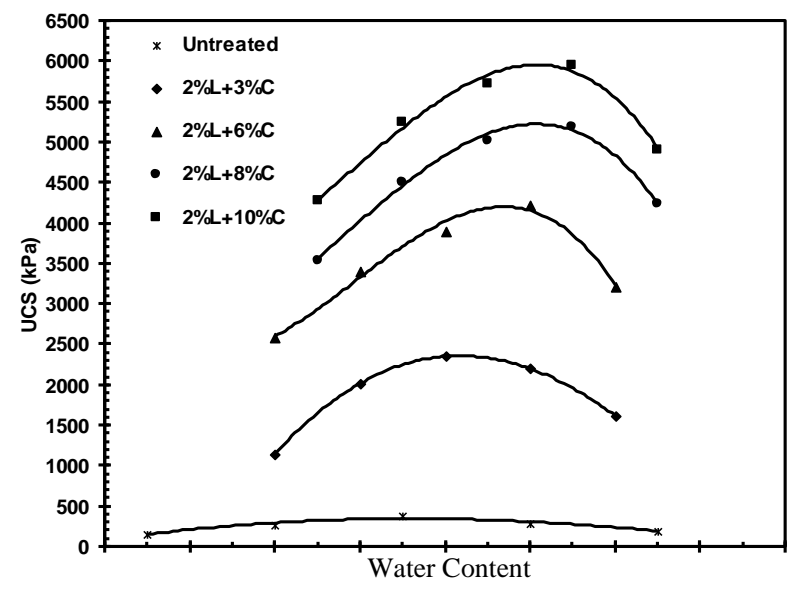

Figure 6. UCS of soil treated with 2 $\%$ lime with different percentages of

The liquid and plastic limits of soil treated with lime-cement percentages added to it are shown in Table 5, the mellowing period was 10 minutes. It is clear that the soil turn to nonplastic at both percentages.

Table 5. Some engineering properties of limecement treated soil.

\begin{tabular}{|c|c|c|c|c|}
\hline Lime- & \multirow{2}{*}{$\begin{array}{c}\text { cement } \\
\text { percent }\end{array}$} & \multirow{2}{*}{$\begin{array}{c}\text { PI } \\
(\%)\end{array}$} & $(\%)$ & \multicolumn{2}{|c|}{$\begin{array}{c}\text { Standard effort } \\
\left(\mathrm{kN} / \mathrm{m}^{3}\right)\end{array}$} & $\begin{array}{c}\text { OMC } \\
(\%)\end{array}$ \\
\hline 0 & 56 & 28 & 15.69 & 23 \\
\hline $1-3$ & $\mathrm{NP}$ & $\mathrm{NP}$ & 15.42 & 24 \\
\hline $2-9$ & $\mathrm{NP}$ & $\mathrm{NP}$ & 14.06 & 25 \\
\hline
\end{tabular}

\section{Results and Discussion}

\section{Permeability of Natural Soil}

The samples were prepared at different moisture content and different dry unit weight as shown in Table 6. Figure 8 shows a reduction in the permeability with increasing both of dry unit weight and compaction moisture content. From the test, it is found that the coefficient of permeability $(\mathrm{k})$ of natural soil compacted at maximum dry unit weight (MDD) and optimum moisture content (OMC) is equal to $7.9 * 10^{-8} \mathrm{~cm} / \mathrm{sec}$. Hence, the soil is classified as impermeable [11] depending on soil type and coefficient of permeability.

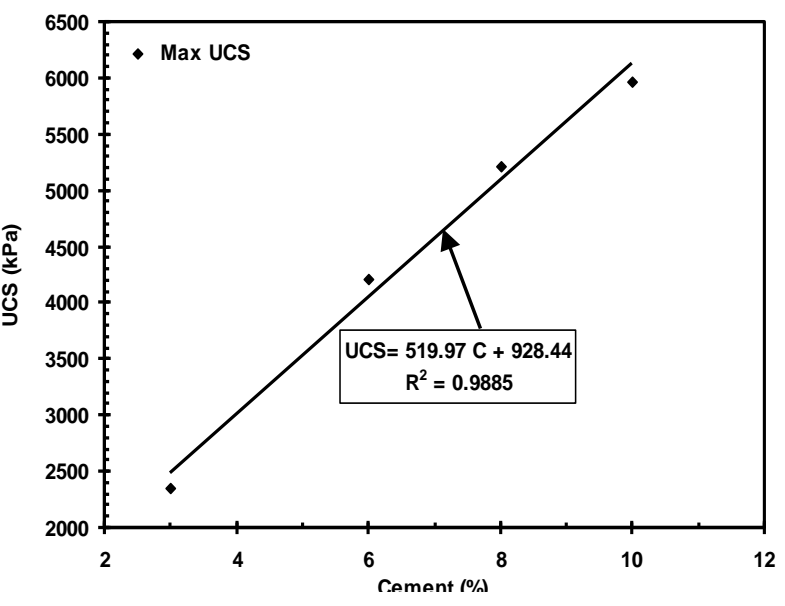

Figure 7. Relationship between maximum UCS and cement content of soil treated with $2 \%$ lime with

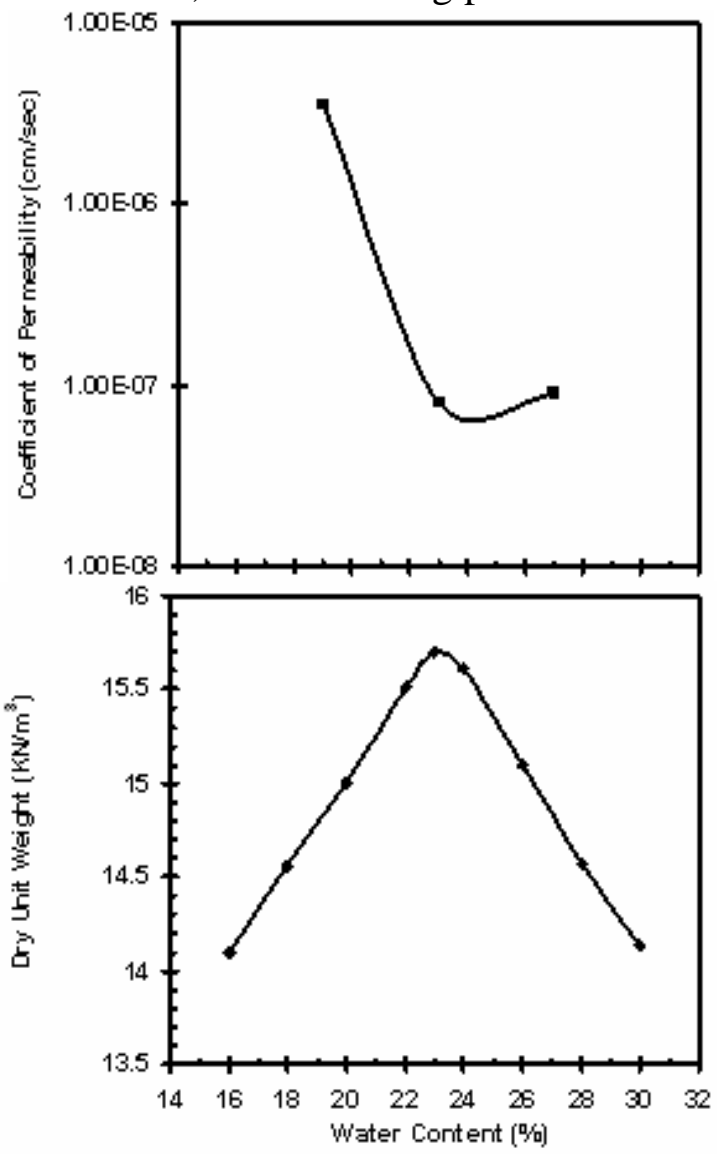

Figure 8. variation of coefficient of permeability corresponding to compaction curve. 


\section{Effect of Additives on Permeability of Treated Soil}

Figure 9 presents the variation in the coefficient of permeability according to curing time initial placement conditions (water content and dry unit weight). Results show an increase in permeability of soil treated with lime at all curing conditions compared with permeability of natural soil. This could be explained by the change in soil structure of lime treated soil; the cation exchange with $(\mathrm{Ca}++)$ ions produced from lime addition is expected to causes a reduction in the ionic layer in treated soil, thus creating a flocculated structure. Also, this Figure shows that this effect in the dry side of compaction curve was larger than that at the wet side. In the other side, Table 7 indicates an increase between 1.2 to 17 folds in the wet side ( 2 days curing time) and in the dry side at (28 days curing time) respectively compared with the permeability of natural soil.
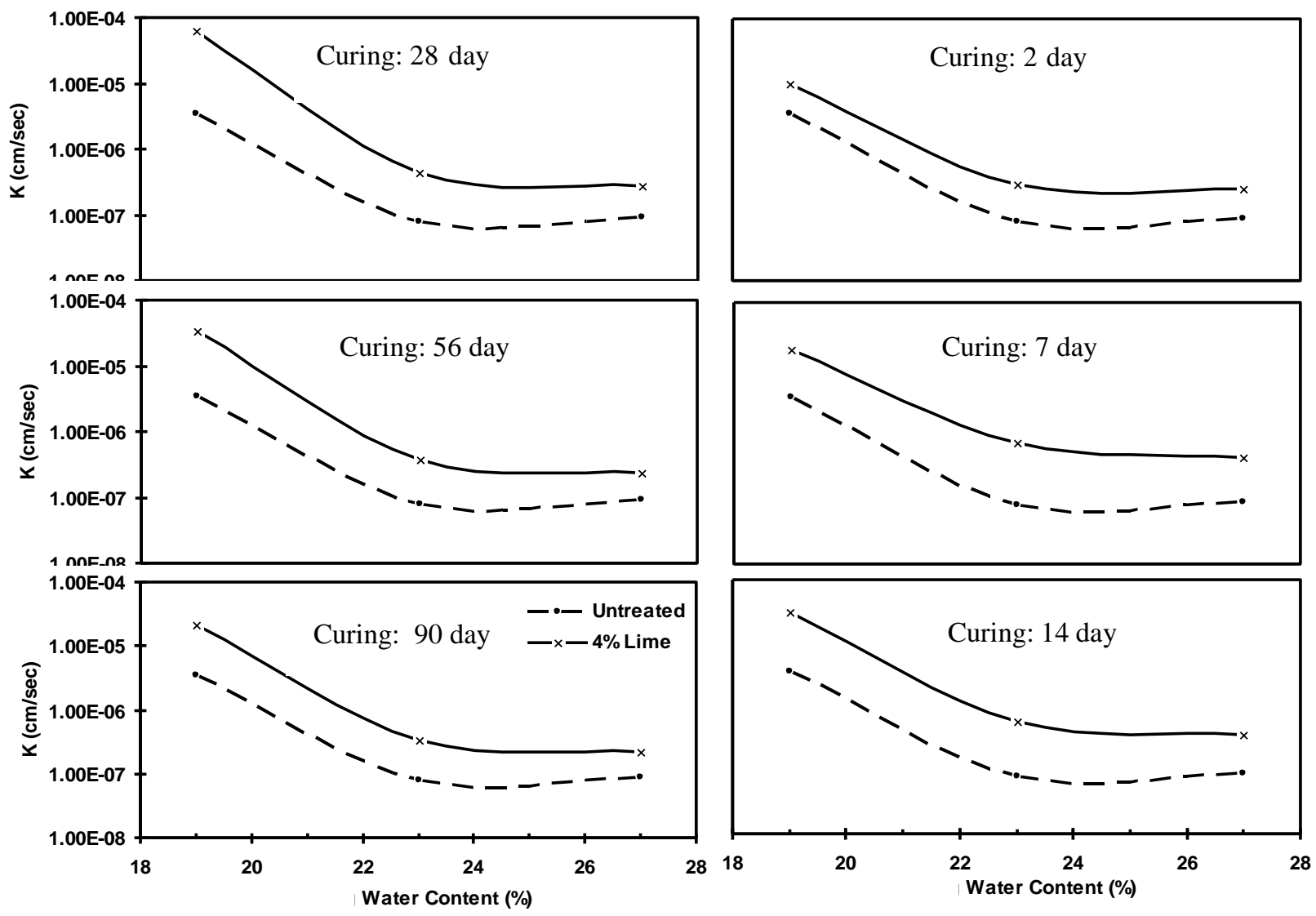

Figure 9. Relationship between coefficient of permeability and moisture content of soil samples treated with $4 \%$ lime at different curing times. 
Table 7. Variation in treated soil permeability of natural soil permeability.

\begin{tabular}{|c|c|c|c|c|c|c|c|c|c|c|}
\hline \multirow[b]{2}{*}{$\begin{array}{l}\text { Additives } \\
\text { percentages }\end{array}$} & \multirow[b]{2}{*}{$\begin{array}{l}\text { Curing } \\
\text { time } \\
\text { (day) }\end{array}$} & \multicolumn{3}{|c|}{ Dry Side } & \multicolumn{3}{|c|}{$(\mathrm{OMC})$} & \multicolumn{3}{|c|}{ Wet Side } \\
\hline & & $\begin{array}{c}\text { Coefficient } \\
\text { of } \\
\text { permeability } \\
\text { (cm/ sec) }\end{array}$ & $\begin{array}{l}\text { No. } \\
\text { of } \\
\text { folds }\end{array}$ & $\begin{array}{c}\text { Increa sing } \\
(\%)\end{array}$ & $\begin{array}{c}\text { Coefficient } \\
\text { of } \\
\text { permeability } \\
\text { (cm/sec) }\end{array}$ & $\begin{array}{l}\text { No. } \\
\text { of } \\
\text { folds }\end{array}$ & $\begin{array}{c}\text { Increa sing } \\
(\%)\end{array}$ & $\begin{array}{c}\text { Coefficient } \\
\text { of } \\
\text { permeability } \\
\text { (cm/sec) }\end{array}$ & $\begin{array}{l}\text { No. } \\
\text { of } \\
\text { folds }\end{array}$ & $\begin{array}{c}\text { Increa sing } \\
(\%)\end{array}$ \\
\hline Untreated & & $3.5 \times 10^{-5}$ & & & $7.9 \times 10^{-5}$ & & & $9.0 \times 10^{-5}$ & & \\
\hline \multirow{4}{*}{$4 \%$ Lime } & 2 & $1.02 \times 10^{-5}$ & 2.9 & 188 & $2.94 \times 10^{-7}$ & 3.7 & 271 & $2.51 \times 10^{-1}$ & 2.8 & 178 \\
\hline & 7 & $1.86 \times 10^{-5}$ & 52 & 424 & $7.21 \times 10^{-7}$ & 9.1 & 809 & $4.23 \times 10^{-7}$ & 4.7 & 368 \\
\hline & 14 & $3.01 \times 10^{5}$ & 8.5 & 749 & $5.86 \times 10^{-7}$ & 7.4 & 639 & $3.66 \times 10^{-5}$ & 4.1 & 306 \\
\hline & 28 & $6.17 \times 10^{-3}$ & 17.4 & 1638 & $4.4 \times 10^{-1}$ & 5.5 & 454 & $2.79 \times 10^{-7}$ & 3.1 & 209 \\
\hline
\end{tabular}

Figure 10 again shows increasing in permeability due to cement addition at all curing periods compared with the permeability of natural soil. This could be attributed to the same reason that previously cited at lime addition. The samples that treated with $6 \%$ cement showed a higher permeability than that treated with $18 \%$ cement, where the maximum increase in permeability are about ( 8 to 12 ) folds compared with the permeability of natural soil (in the dry side and at curing time 28 days) respectively. This may be due to the formation of a hardened materials in the samples treated with $18 \%$ cement and the presence of an additional un reacted amounts of cement.
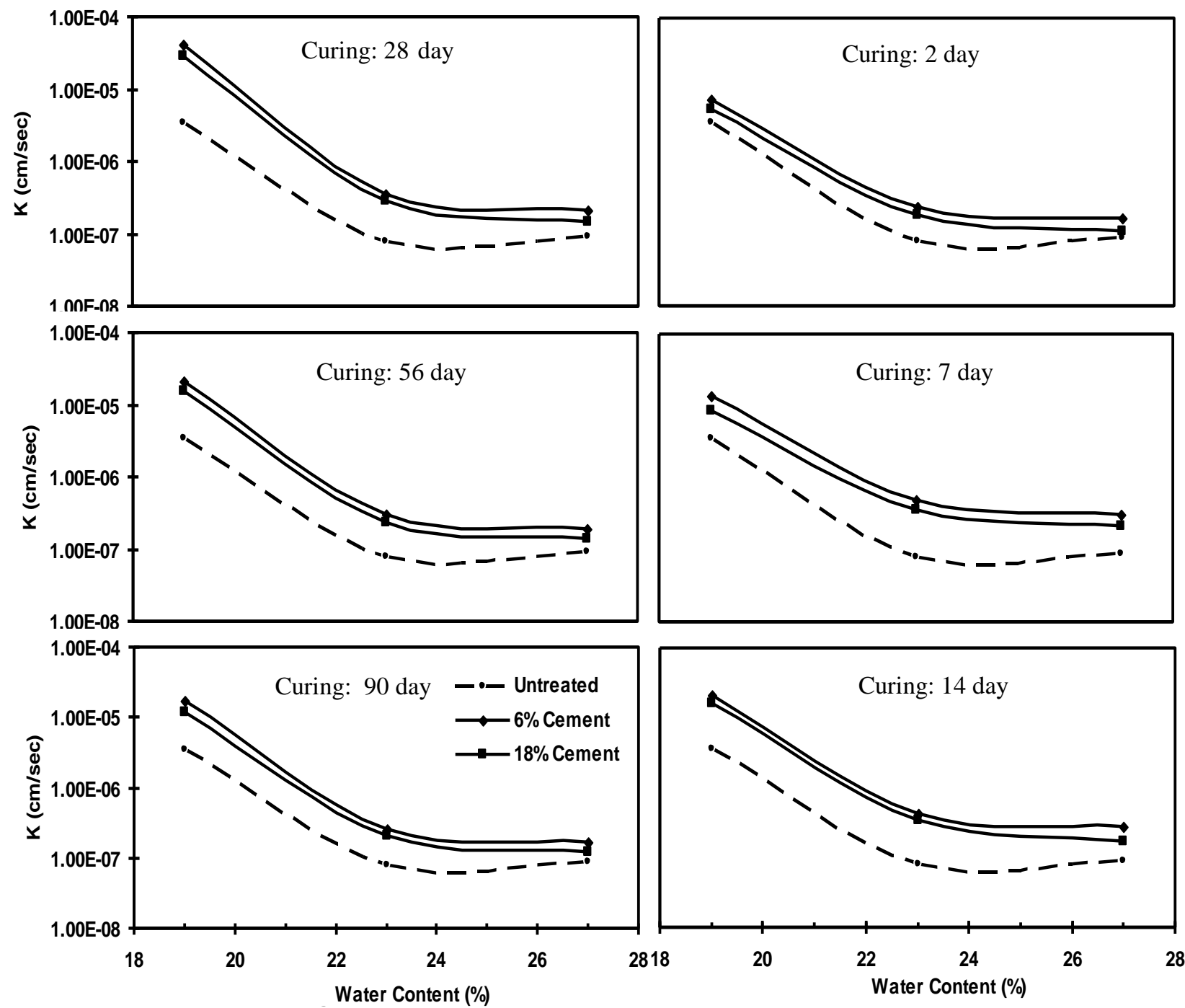

Figure 10. Relationship between coefficient of permeability and moisture content of soil samples treated with 6 and 18\% cement at different curing times. 
On the other hand, the samples treated with 1-3\% lime-cement showed a higher permeability than that treated with $2-9 \%$ lime-cement, where the more increase in permeability about (10 to 13) folds compared with the permeability of natural soil (in the dry side and at curing time 28 days) respectively as shown in Figure 11. This is due to the same reason that previously cited in the soil treated with cement. Comparing between permeability of the soil samples treated with cement that achieving the lower and upper limit of unconfined compressive strength with permeability of the soil samples treated with limecement; The samples that treated with 1-3\% lime-cement showed small increase in permeability compared with the samples that treated with $6 \%$ cement, where the more increase in permeability is about (12 to 13) folds compared with the permeability of natural soil (in the dry side and at curing time 28 days) respectively. The treated samples with 2-9\% lime-cement showed small increase in permeability compared with the samples that treated with $18 \%$ cement, where the more increase in permeability is about ( 8 to 10) folds compared with the permeability of natural soil (in the dry side and at curing time 28 days) respectively. It is worth noting that, all the cement treated soil samples showed permeability values less than that treated with lime.
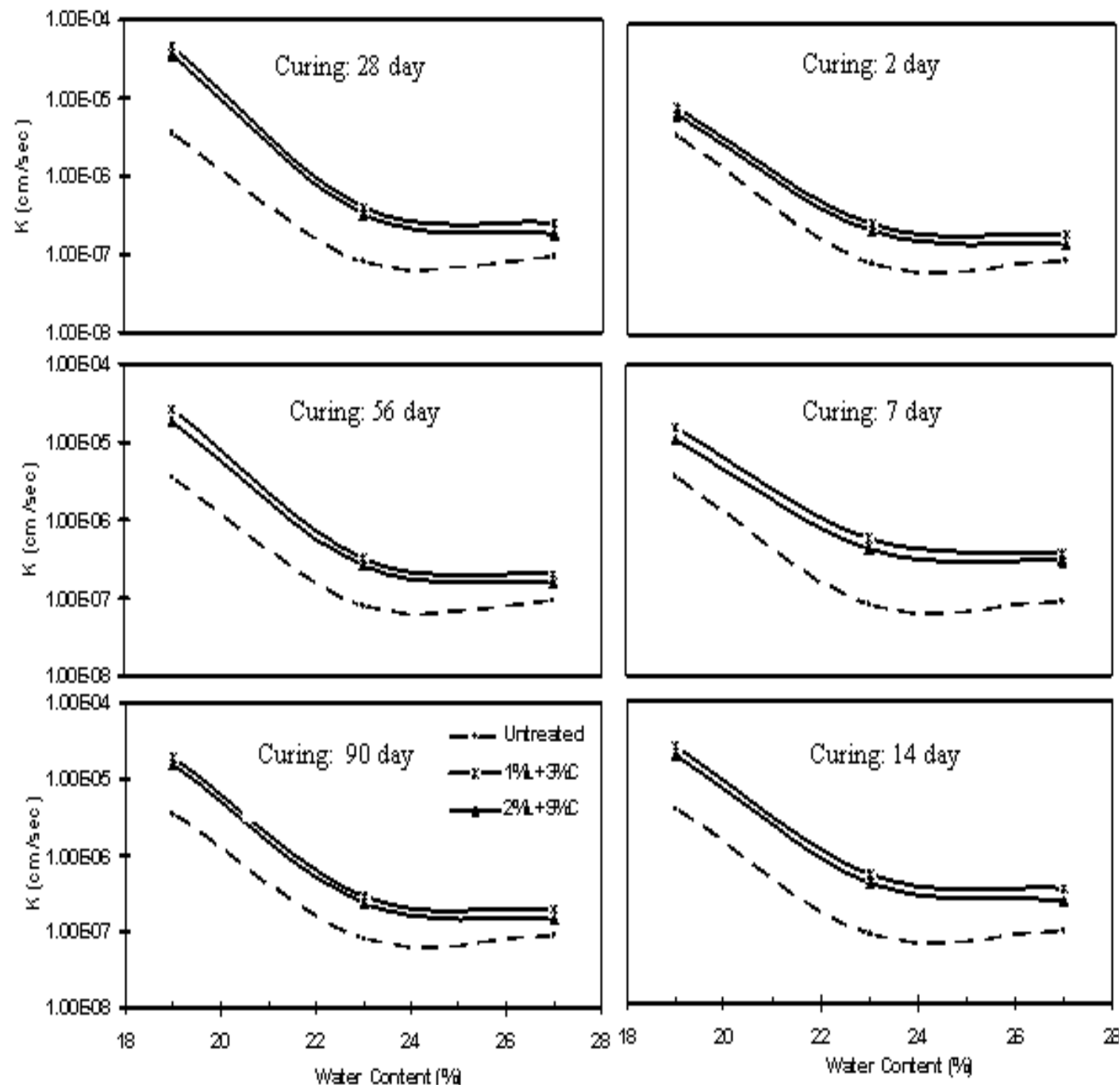

Figure 11. Relationship between coefficient of permeability and moisture content of treated soil samples with (1-3, 2-9) \% lime-cement at different curing times. 


\section{Effect of Moisture Content on Permeability of Treated Soil}

The results shown in Figure 12 indicate an increase in the permeability of treated soil compared with that of natural soil under the same compaction conditions. This increasing covers all the moisture percentages. The results showed also, that the permeability of treated soil with certain percentage of additives compacted in the wet side were less than that compacted in optimum moisture content and in the dry side. This could be attributed to the flocculation-agglomeration beside the role of moisture in the formation of soil structure. Here, the particles arrangement changes from the parallel structure to the flocculated structure which consequently increase the voids ratio and permeability. A similar results was mentioned by (Khattab, S. A. A. 2002) [10]. On the other hand, the maximum increase in the permeability was noted in the lime treated soils with $4 \%$ compared with that of natural soil and cement and lime-cement treated soils in all the studied cases. As example, the lime addition to samples prepared at the dry side leads to 17 folds increase in permeability (curing time 28 days), while, an increase of 9 and about 5 folds were noted for the samples compacted at the optimum moisture content and wet side respectively at 7 days curing time.
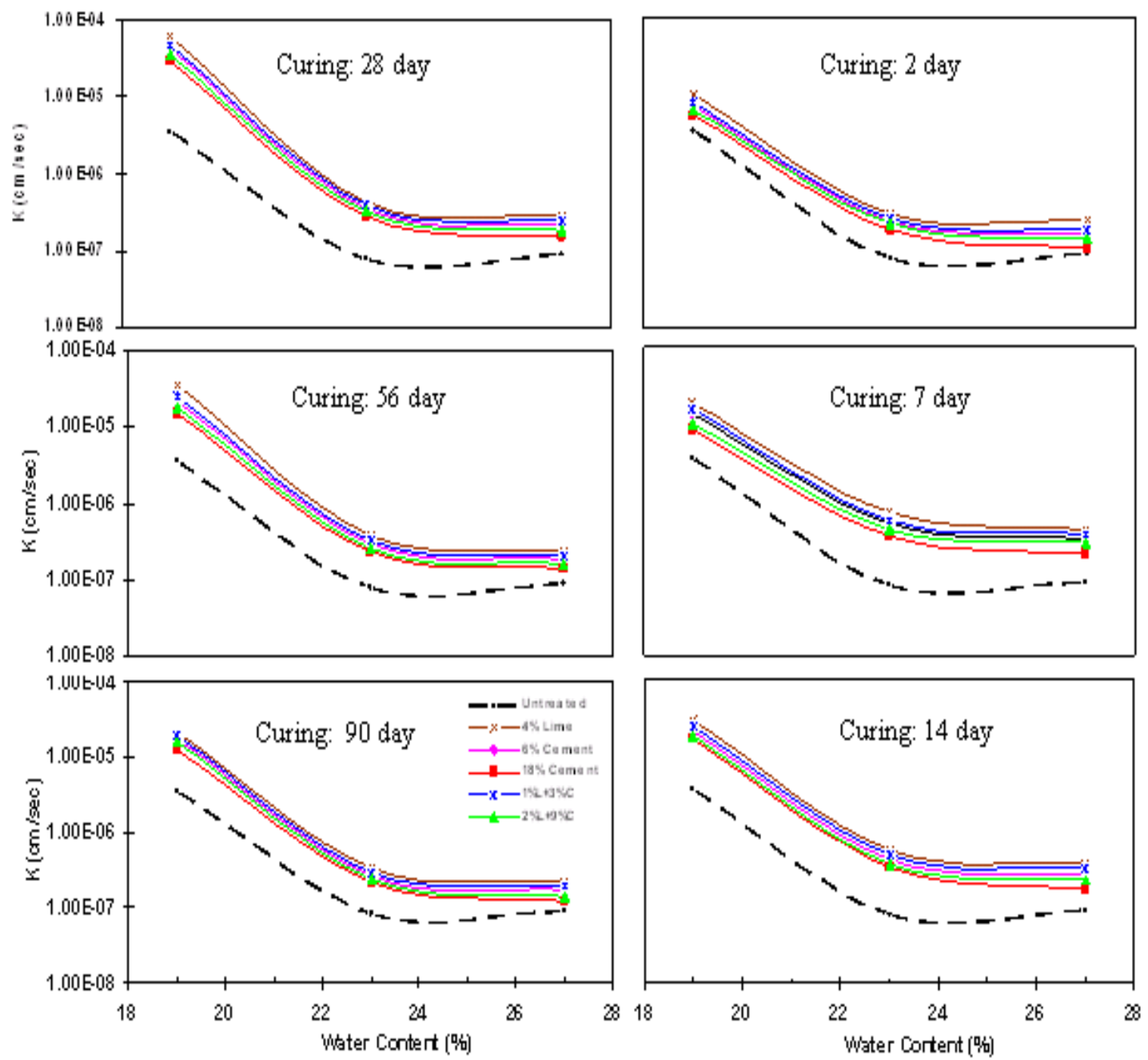

Figure (12). Effect of moisture content on coefficient of permeability of treated soil samples.

More variation of the coefficient of permeability of the treated soil in the dry side was between $3.42 * 10^{-5} \mathrm{~cm} / \mathrm{sec}$ (soil treated with $4 \%$ lime) to $1.52 * 10^{-5} \mathrm{~cm} / \mathrm{sec}$ (soil treated 
with $18 \%$ cement) at curing time 56 days, where at the optimum moisture content was between $7.21 * 10^{-7} \mathrm{~cm} / \mathrm{sec}$ (soil treated with $4 \%$ lime) to $3.6 * 10^{-7} \mathrm{~cm} / \mathrm{sec}$ (soil treated with $18 \%$ cement) at curing time 7 days. Finally more variation in the wet side was between 4.23 $* 10^{-7} \mathrm{~cm} / \mathrm{sec}$ (soil treated with $4 \%$ lime) to $2.11 * 10^{-7} \mathrm{~cm} / \mathrm{sec}$ (soil treated with $18 \%$ cement) at curing time 7 days.

\section{Effect of Curing Time on Permeability of Treated Soil}

Figures $(13,14$ and 15) present the effect of curing times on the values of coefficient of permeability. It is clear that the coefficient of permeability increases at the earlier curing times (between 7-28) days followed by a reduction in different rates with increasing of curing times for all the studied cases. This could be explained by the flocculation process in the first days and after that to the formation of the pozzolanic reaction products that cause closing some of water paths. Identical results are noted (Khattab, 2002) [10], while (EL-Rawi, \& Amir, 1981) [6] noticed a continuous reduction in permeability with increasing of curing times.

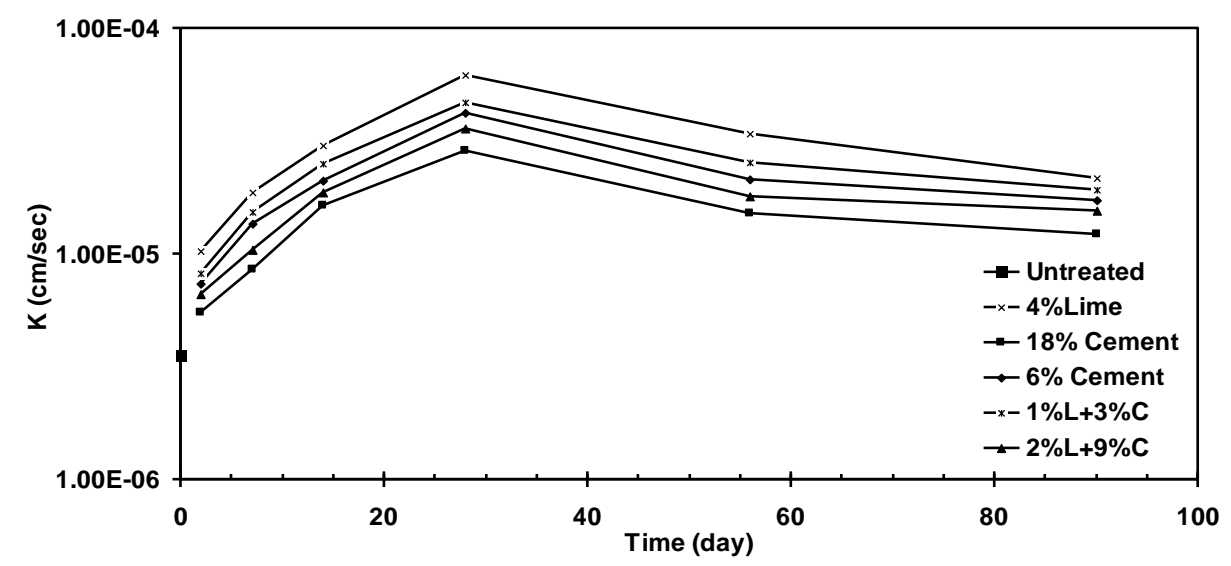

Figure 13. Effect of curing time on coefficient of permeability of treated soil samples in dry side.

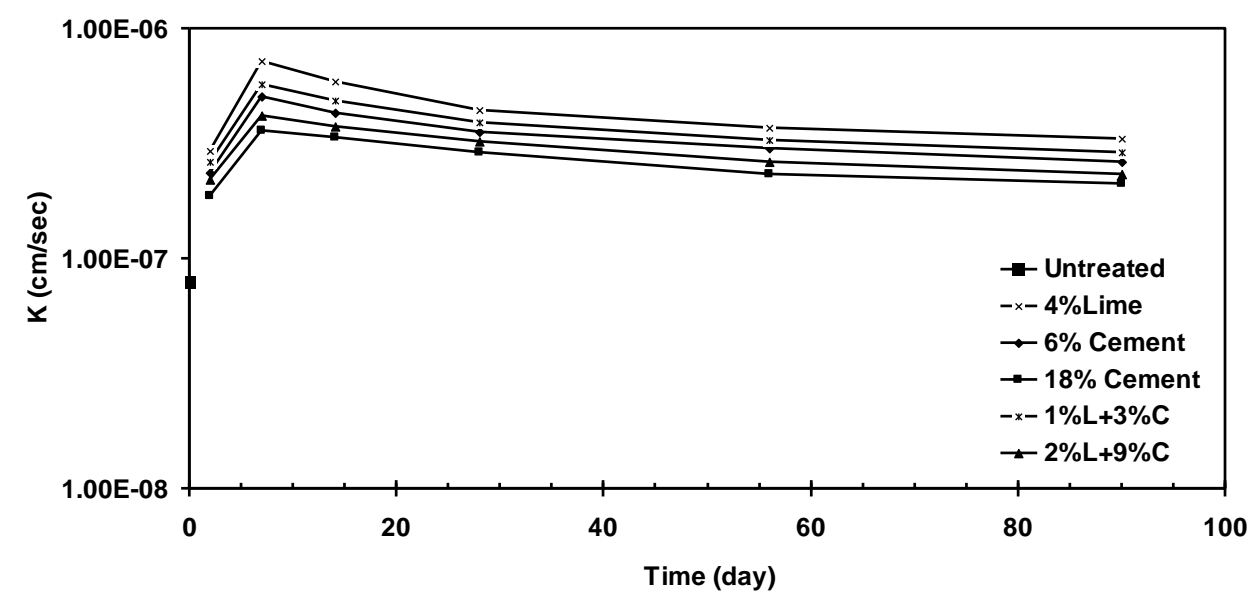

Figure 14. Effect of curing time on coefficient of permeability of treated soil samples at optimum moisture content. 


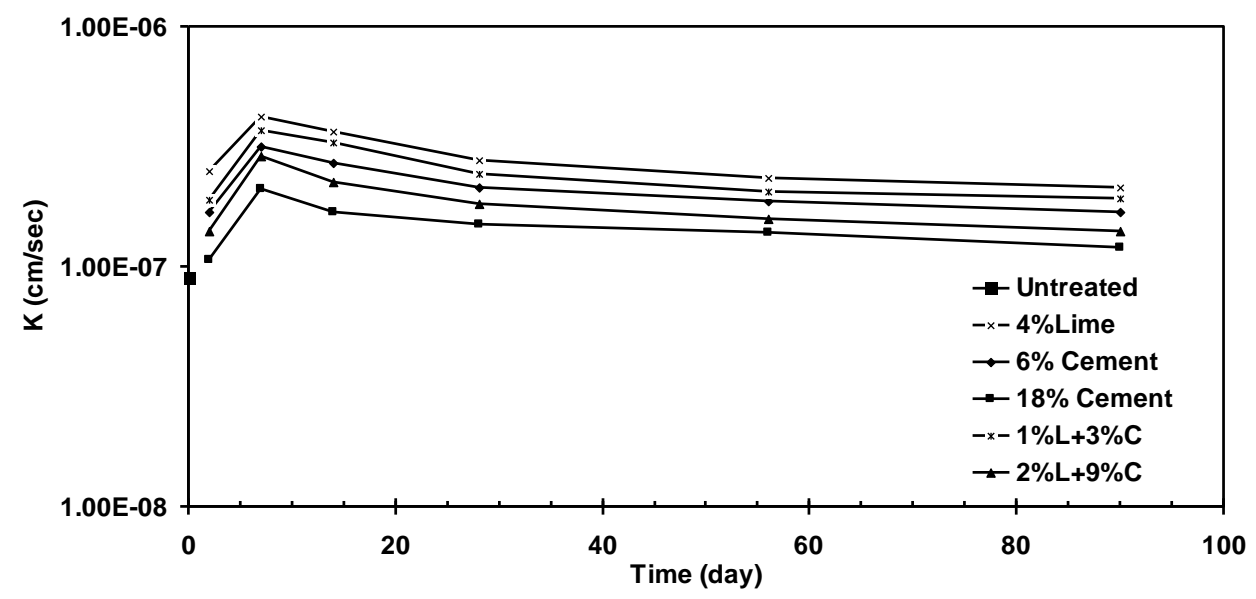

Figure 15. Effect of curing time on coefficient of permeability of treated soil samples in wet side.

The more increasing in permeability of the treated soil samples was at curing time 28 days in the dry side, where the more increasing in permeability of the treated soil samples was at curing time 7 days at the optimum moisture content and in the wet side. This may be attributed to the effect of moisture percentage on the chemical reaction operations for lime-cement and cement hydration.

\section{Effect of Additives on SWCC for Treated Soil}

It is shown from Figure (16) that the water holding capacity increases with the addition of additives. The SWCC's for treated soil samples with $4 \%$ lime were the closest to SWCC for natural soil and located in the lower part of the figure. While the SWCC for treated soil samples followed the sequence of increasing the water holding capacity as; 1-3 \% lime-cement, $4 \%$ lime, $6 \%$ cement, 2-9 \% lime-cement and finally the SWCC for treated soil samples with $18 \%$ cement in the upper part of the figure. This could be explained by the fact that the higher percentages of additives lead to a more hardened products compared with the small percentages. These products will be expected to construct a more open structure, and the excessive amount of additives act as fine material which fill some pores, and hence, increasing water holding capacity for soil.

It could be also noted that there was an interaction between SWCCs at high suction ranges, Figure (16). This behavior was due to the insufficient amount of water for the reactions to proceed because of the high suction applied

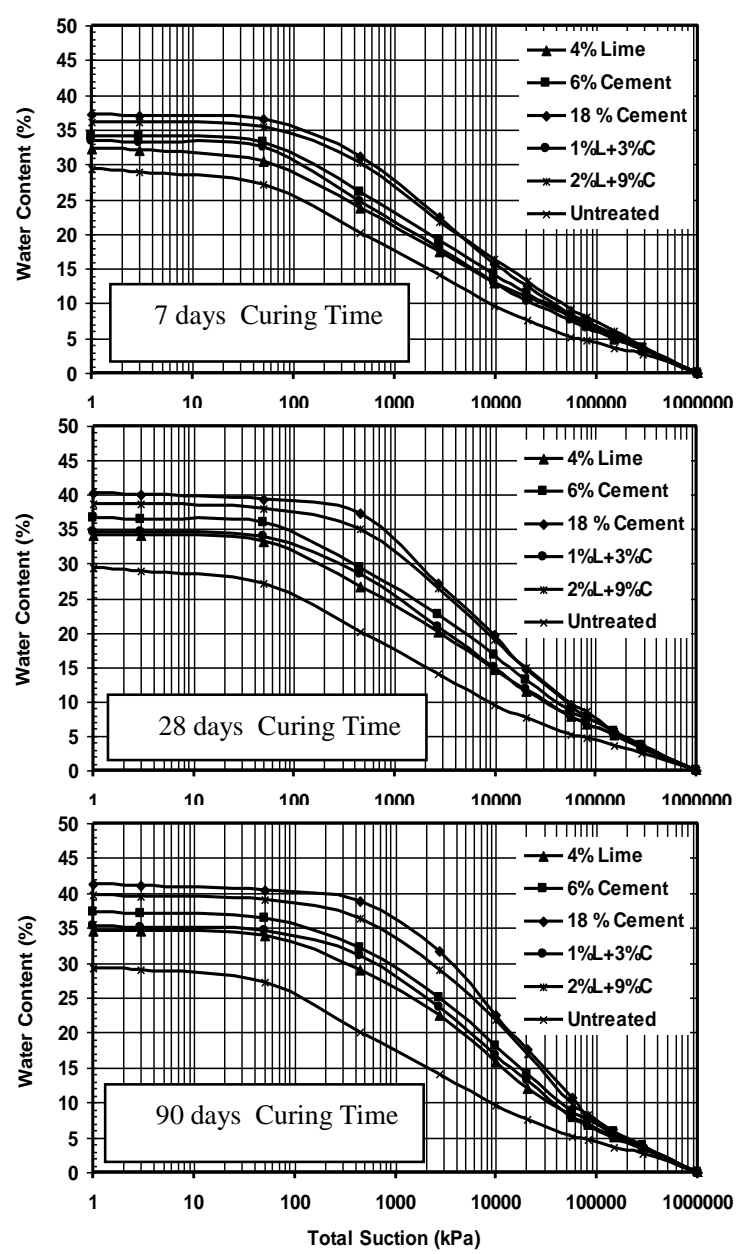

Figure 16. SWCC of treated soil samples that prepared at maximum dry unit weight and optimum moisture content. 
along the equilibrium time. Subsequently, ineffective role of additives on this part of the curve behavior. This agrees with the obtained results by (Al-Taie, L. Kh. 2005) [2].

Finally, Table (8) indicates that the air-entry value and residual suction were increased with additives percentages, and the boundary effect zone and transition zone were also expanded. This could be attributed to the addition of lime and/or cement to soil and its above stated effects on the soil structure

Table 8. SWCC parameters for natural and treated soils.

\begin{tabular}{|c|c|c|c|c|c|}
\hline \multirow{2}{*}{$\begin{array}{c}\text { Additives } \\
\text { percentages }\end{array}$} & \multirow{2}{*}{$\begin{array}{c}\text { Curing } \\
\text { time (days) }\end{array}$} & \multicolumn{2}{|c|}{ Air-Entry Parameters } & \multicolumn{2}{c|}{$\begin{array}{c}\text { Residual State } \\
\text { Parameters }\end{array}$} \\
\cline { 3 - 6 } & & $W_{a}(\%)$ & $\Psi_{a}(\mathrm{kPa})$ & $W_{r}(\%)$ & $\Psi_{r}(\mathrm{kPa})$ \\
\hline Untreated & & 29 & 32 & 9 & 12000 \\
\hline \multirow{3}{*}{$4 \%$ Lime } & 7 & 32 & 50 & 10 & 17000 \\
\cline { 2 - 6 } & 28 & 34 & 90 & 9.5 & 24000 \\
\cline { 2 - 6 } & 90 & 34.5 & 300 & 7.5 & 50000 \\
\hline \multirow{3}{*}{$6 \%$ Cement } & 7 & 34 & 60 & 11 & 19000 \\
\cline { 2 - 6 } & 28 & 36.5 & 110 & 10 & 27500 \\
\cline { 2 - 6 } & 90 & 37 & 350 & 8 & 58000 \\
\hline \multirow{3}{*}{$18 \%$ Cement } & 7 & 37 & 170 & 10 & 30000 \\
\cline { 2 - 6 } & 28 & 40 & 320 & 9 & 42000 \\
\cline { 2 - 6 } & 90 & 41 & 960 & 7 & 89000 \\
\hline & 7 & 33 & 55 & 10.5 & 18000 \\
\cline { 2 - 6 } & 28 & 34.5 & 100 & 10 & 25500 \\
\hline \multirow{3}{*}{$2 \% \mathrm{~L}+9 \% \mathrm{C}$} & 90 & 35 & 320 & 8.5 & 54000 \\
\cline { 2 - 6 } & 7 & 36 & 160 & 10 & 28000 \\
\cline { 2 - 6 } & 28 & 38.5 & 300 & 9.5 & 41000 \\
\hline
\end{tabular}

$W_{a}$ : Air entry water content.,$\psi_{\mathrm{r}}$ : Suction corresponding to the air entry water content. , $W_{r}$ : Residual water content. $\psi_{\mathrm{r}}$ : Suction corresponding to the residual water content. Effect of Curing Time on SWCC for Treated Soil

Figures (17 to 21) show the effect of curing times on the SWCCs. It was noticed that SWCCs move upward as curing time proceeds, where the suction value was increased at any value of moisture content at curing time proceeding from (7-90) days. This is expected to be due to the curing time that causes the formation of a more hardened products and more open soil structure, leading to a structure with high water holding capacity.

On the other hand, it was noted that, in general, there is a divergence of SWCCs till 28 days in boundary effect zone and transition zone, followed by convergence till reaching 90 days curing time in boundary effect zone and transition zone. This could be attributed to the decrease in the rate of hardened materials formation in the time between 28 and 90 days compared with that from 0 to 28 days. Finally, a convergence of SWCCs was observed at residual zone of treated soil specimens.

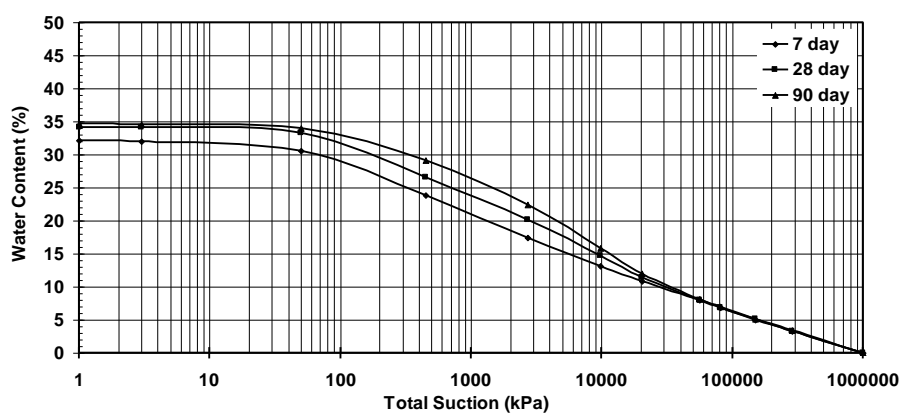

Figure 17. Effect of curing time on SWCC of treated soil samples with $4 \%$ lime. 


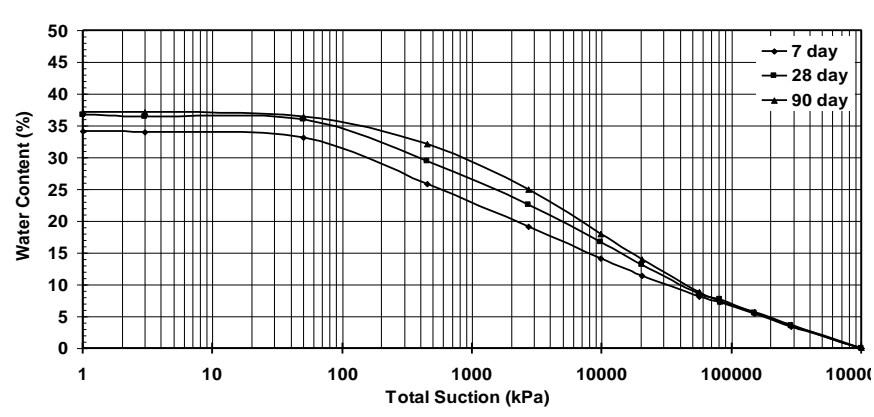

Figure 18. Effect of curing time on SWCC of treated soil samples with $6 \%$ cement.

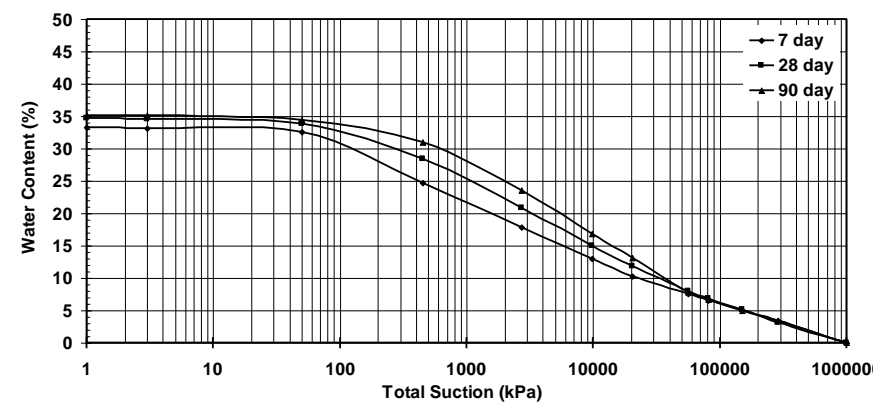

Figure 20. Effect of curing time on SWCC of treated soil samples with (1-3) \% lime-cement.

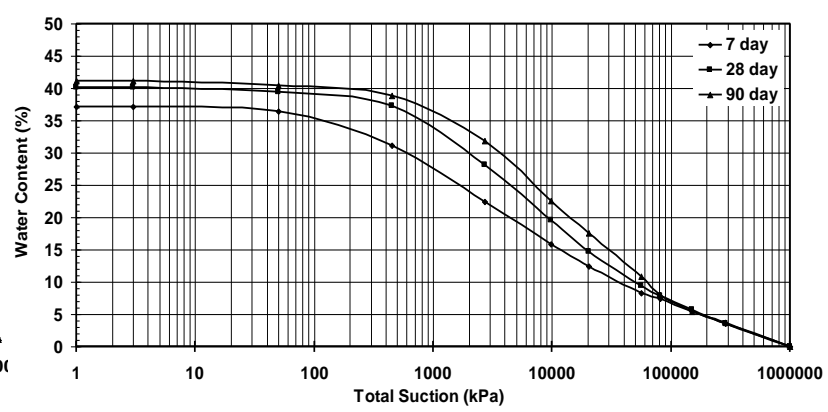

Figure 19. Effect of curing time on SWCC of treated soil samples with $18 \%$ cement.

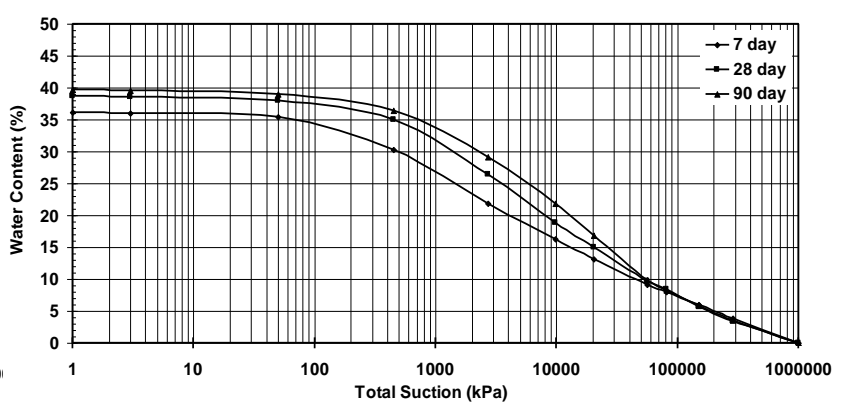

Figure 21. Effect of curing time on SWCC of treated soil samples with (2-9) \% lime-cement.

\section{CONCLUSIONS}

The following conclusions could be obtained from this work considering the limits and soil type of this study

1. The combined stabilization using more than one stabilizer was found to be more economic over than using single stabilizer alone for the selected clayey soil from Mosul city. Soil stabilized with (2-9) \% lime-cement was found to attain nearly an identical strength of that treated with $18 \%$ cement.

2. Permeability of natural soil was found to increase with treatment of lime, cement and lime-cement.

3. More permeability is noticed for the samples compacted in dry side of the compaction curve for both natural and treated soil, while less permeability is observed for the samples compacted in wet side of the compaction curve of the treated soil.

4. All the studied conditions on soil-water characteristic curves had $(S)$ shape curve for natural and treated soils.

5. Water holding capacity for the treated soil was increased due to the increase in additive percentages.

6. Air-entry value and residual suction were increased with additive percentages, while the boundary effect and transition zones were also expanded.

\section{References}

1. Al-Rawas, A. A., Taha, R., Nelson, J. D., Al-Shab, T. B. \& Al-Siyabi, H. (2002), "A Comparative Evaluation of Various Additives Used in the Stabilization of Expansive Soils", Geotechnical Testing Journal, GTJODG, Vol. 25, No. 2, June, pp. 199-209.

2. Al-Taie, L. Kh. (2005). "Correlation between suction and some engineering properties of lime stabilized clay soil from mosul city.” M.Sc. Thesis, University of Mosul, Iraq. 
3. Bell, F.G. (1996), "Lime Stabilization of Clay Minerals and Soils", Engineering Geology 42, pp.223- 237.

4. Burroughs, V. S. (2001), "Quantitative Criteria for the Selection and Stabilisation of Soils for Rammed Earth Wall Construction", Ph.D Thesis, Faculty of the Built Environment, University of New South Wales.

5. Eades, J.B. \& R.E. Grim (1966). “A Quick Test to Determine Lime Requirement for Lime Stabilization.” Highway Research Board , No. 139.

6. Ingles, O. G. \& Metcalf, J. B. (1972), "Soil Stabilization, Principle and Practice", Butterworths Pty Limited, Australia.

7. Federal Highway Administration Office of Development (1979), "Soil Stabilization in Pavement Structures A User's Manual" Vol. 2, October, No. FHWA-IP-80-2.

8. Fredlund, M.D., D.G. Fredlund \& G.W. Wilson (1997), "Prediction of the Soil-Water Characteristic Curve from Grain-Size Distribution \& Volume-Mass Properties", $3^{\text {rd }}$ Brazilian Symposium on Unsaturated Soils, Rio de Janeiro, April 22-25.

9. Hicks, R. G. (2002), "Alaska Soil Stabilization Design Guide", Alaska Department of Transportation and Public Facilities, FHWA-AK-RD-01-6B.

10. Khattab, S. A. A. (2002), "Eude Multi-echelles d'un Sol Plastique Traite' a' la Chaux", Thèse de Doctorat, L' Universitee' d' Orleans, France.

11. Terzaghi, K. \& Peck, R.B. (1969), "Soil Mechanics in Engineering Practice”, John Wiley and Sons, INC New York.

12. Thompson, M. R. (1970). "Suggested Method of Mixture Design Procedure for LimeTreated Soils." American Society of Testing and Materials, STP 479. 